\title{
Civil law and the role of the State
}

\author{
ATTILA HARMATHY*
}

Faculty of Law, Eötvös Loránd University, Budapest, Hungary

\section{ORIGINAL RESEARCH PAPER}

Received: November 7, 2020 • Accepted: May 11, 2021

Published online: October 19, 2021

(C) 2021 The Author(s)

\begin{abstract}
The profound changes in both everyday life and the legal system over the last hundred years have transformed civil law as well. While the notion that civil law concerns relationships of private persons still prevails, the traditional public law-civil law division now seems questionable. This paper points out some of the key changes in civil law within the framework of the transformation of the legal system as a whole, and seeks to outline a different approach that may help better to understand the present situation.
\end{abstract}

\section{KEYWORDS}

legal system, civil law, state, legal traditions

1. During the last hundred years conditions of life have changed profoundly. The changes have transformed the legal system, both rules and role of civil law in the framework of the system too. The basic concept that the civil law concerns relationships of private persons seems nevertheless to prevail. Under the new conditions the traditional public law-civil law division seems, however, to be questionable and a somewhat different approach (including mixed relationships) may help to get a better understanding of the present situation. The present paper hints at some elements of the changes of the civil law in the framework of the changes of the legal system as a whole.

2. As a starting point Coing's statement can be referred to. Coing has pointed out that after the Middle Ages fundamental institutions of civil law were transformed as a result of changes in

\footnotetext{
*Corresponding author. E-mail: harmathy@ajk.elte.hu
} 
society, economy, politics and functioning of the state. ${ }^{1}$ Economies are embedded within social and political structures and society helps to structure the state. ${ }^{2}$ Industrialisation and urbanisation have changed production units, role of family, and there is an important transformation of social values influencing civil law rules. ${ }^{3}$

The role of civil law in the legal system is closely connected with the role of the state. Although the law of commerce developed outside seigniorial courts for a long time it became a part of state law due to a great extent of the mercantilist policy. ${ }^{4}$ From the point of view of the present paper the general analysis of the development worked out by Heckscher can serve as a basis. Heckscher has emphasised the importance of the rise and development of the state in the economic development. As he put it: the state was both the subject and the object of mercantilist economic policy. The state was an agent of a unified economic sphere. ${ }^{5}$ Mercantilism achieved the more in France and the less in Germany among states of Western Europe. Mercantilism did not mean, however, strong state activity in economic affairs, but private initiative was decisive, stimulated and directed by government measures. ${ }^{6}$

A fundamental change started in the 18th century. There was an important transformation in economic organisation, specialisation of labour, change of technology, growth of population, overseas trade. Considerable differences evolved in Europe: Holland, England and France were the leading countries. ${ }^{7}$ The changes meant introduction of new goods, new method of production, opening of markets, new sources of raw materials, organisation of the economy and need for credit. The transformation needed proper social environment and legal, political system as well. ${ }^{8}$ Mercantilist approach was replaced by the so-called classical economic theory concentrating on individuals shaping their own ends and having a poor opinion of the wisdom of government. ${ }^{9}$ Only a limited role of the state was admitted by Adam Smith who was a leading theorist of the period. According to him taxes, privileges, monopolies instituted by law hindered commerce. His main thesis was that it is by no means certain that an artificial direction by regulation is likely to be more advantageous to the society than that into which it would have gone of its own accord. ${ }^{10}$ Nevertheless he admitted that different kinds of state activity (such as maintaining order, enforcing contractual obligations) were conditions of commerce. ${ }^{11}$

3. Continuing changes of technics, demographic trends, structure of labour force, new conditions of life led to transformation of the social structure and of the ideology prevailing in

\footnotetext{
${ }^{1}$ Coing (1982) 3-7; Coing (1989) 3-14.

${ }^{2}$ Block and Evans (2005) 505.

${ }^{3}$ Parsons (1966) 22-26; Hoselitz (1960) 45-46, 60.

${ }^{4}$ Basedow (2008) 704-706.

${ }^{5}$ Heckscher (1994) 20-22.

${ }^{6}$ Heckscher (1994) 337-38.

${ }^{7}$ Cole and Deane (1966) 1-4.

${ }^{8}$ Schumpeter (1949) 63, 66-67, 86-87.

${ }^{9}$ Robbins (1978) 184.

${ }^{10}$ Smith (2008) 55.

${ }^{11}$ Smith $(1763,1978)$ 494, 528-29.
} 
the society. The changes required new solutions in the legal field, too. ${ }^{12}$ In different European states codification started in the 18th century but the important codes were enacted in the 19th century. England was an exception as no civil code was enacted.

The legal basis of the civil codes was similar: the Roman law tradition. The political, social and economic background of the codes was, however, different. In the codes of the 18th century the political reason was prevailing: unifying, simplifying and rationalising legal rules of the state. This tendency could be observed in Prussia and the first period of the preparatory work in Austria. ${ }^{13}$ The elaboration of the Austrian civil code was long and prevailing political concepts changed during this period, partly under the influence of the fear of the effects of the French revolution. ${ }^{14}$ At the very beginning the main purpose of the codification was unification of legal rules in countries belonging to the Habsburg Empire, simplifying the administration of justice and, in addition, serving interests of trade. ${ }^{15}$ The Habsburg Empire lost a considerable part of its territory during the 19th century; nevertheless, the aim of the unification of legal rules in different countries of Europe remained. The Austrian civil code influenced even rules of countries not belonging to the Austrian ruler. ${ }^{16}$

4. The tendency of unification of legal rules was present in France, too since the modern state started developing and centralisation of power was growing in the 17th and 18th century. Different privileges of the feudal system were, however, serious obstacles to the general unification of law. ${ }^{17}$ The diversity of legal rules in different parts of France hindered the development of trade. In addition, the existing law reflected the feudal system characterised by privileges not only of the king but those of the aristocracy and of the Church. Political elements of the old system were swept away by the revolution but the establishment of the new unified legal system could not be established immediately. Unification of civil law rules was achieved only by the Civil Code of $1804 .{ }^{18}$ Social and economic relations transformed after the revolution profoundly and developed in accordance with the Code so that returning to the uncodified system of the pre-revolutionary period would have caused serious problems in social and economic life. Therefore, the application of the Code was maintained by the Charter of 1814, even after the restoration of the power of the king, with the exception of the rules concerning divorce. ${ }^{19}$

5. The Prussian code of 1794, the Landrecht was more than a civil code. It embraced general rules of social life of an old social-economic-political system. It was characterised by Coing as last will of a system of the past. ${ }^{20}$ In contrast, the French Civil Code was worked out in the early 19 th century in a period close to the revolution when great political, social and economic changes took place.

\footnotetext{
${ }^{12}$ Kuznets (1971) 258, 345.

${ }^{13}$ Wieacker (1952) 202-207.

${ }^{14}$ Pichler (1991) 10-18.

${ }^{15}$ Kodek (2012) 667-68.

${ }^{16}$ Olechowski (2012) 685, 688-90.

${ }^{17}$ Halpérin (2001) 16-17.

${ }^{18}$ Carbonnier (1955) 120-23.

${ }^{19}$ Carbonnier (2014) 213-19.

${ }^{20}$ Coing (1989) 10.
} 
After the downfall of Napoleon a loose cooperation of the different German States, the German Confederation was established. Conditions of the unification of the German states were not yet present. By that time there was, however, a need for unifying rules of economic contacts. In 1834 unification of tariffs was accepted in the framework of Zollverein. Efforts were made to work out common rules of commercial law and by 1861 the draft of a Commercial Code was prepared. The code was enacted at first in Prussia in 1861 and later on by other German states, too. ${ }^{21}$

The decision concerning drafting a unified German Civil Code was made closely connected with the grounding of the unified German state. The original concept of the constitution of the German Empire contained the aim of the unification of the rules concerning the law of obligations only. As a result of political battles, however, the competence of drafting work was enlarged to the whole field of the civil law as it was understood in the civil law theory of the 19th century. Consequently drafting work covered family law, land law and law of succession, too. After political struggles the drafting work resulted in a comprehensive code in August 1896 which entered into force on 1 January $1900 .^{22}$

The German Civil Code was enacted nearly one hundred years after the French Civil Code. During this period society, economy changed considerably in German states too. The code was an important achievement from the point of view of politics, of the creation of a unified state. It was, however, in the words of Wieacker a late born child as it did not reflect social and economic conditions of the end of the 19th century. ${ }^{23}$

6. The German civil code has served the interest of the development of the economy by the unification of rules. The legal technical achievement of the German Civil Code has also been generally acknowledged. At the same time it was characterised by neglecting economic factors, interdependencies - a general feature of the whole of civil law of the $19^{\text {th }}$ century. ${ }^{24}$ In connection with 100 year anniversary of the birth of the code several articles evaluated the code in German literature but the critical approach was rather important. It was emphasized that not only aspects of social policy were neglected but important elements of economic policy of the age were missing, remained outside the code. ${ }^{25}$ By the end of the 19th century fast economic and social changes requested new solutions which were not foreseen in the code and which were reflected by special statutes. ${ }^{26}$

7. The Hungarian legal development had a special way. Several attempts were made for codifying the civil law since the middle of the 19th century. After the defeat of the revolution of 18481849 by the Habsburg king with the help of the Russian army the Austrian law was to be applied in Hungary too. As a result of the compromise between Hungary and the Habsburg king the Hungarian legal system was re-established (with the exception of Transylvania where the Austrian Civil Code remained in force). Drafts of a civil code were worked out and presented to the parliament but none of them were approved prior to World War 2. A Commercial Code

\footnotetext{
${ }^{21}$ Schmoeckel (2008) 100-105.

${ }^{22}$ Wieacker (1952) 279, 282.

${ }^{23}$ Wieacker (1953) 9.

${ }^{24}$ Nörr (2001) 59.

${ }^{25}$ Horn (2000) 40-42.

${ }^{26}$ Coing (1989) 92.
} 
was worked out and approved by the Parliament and a great number of special acts relating to civil law questions were adopted but the whole field of civil law remained judge-made law. Decisions of principle of the Supreme Court were collected and published since early 19th century and had binding force to all courts. The system changed only after World War 2 when as a result of the takeover of the power by the Communist Party the political and economic system was built up on a different basis and a Civil Code (containing a part of the content of the Commercial Code) was adopted by the Parliament in $1959 .^{27}$

8. Social and economic factors of the development can help to get a better understanding of the legal development. An important element of the transformation of economic life was money. Even in the 18th century the typical form of trade was exchange of goods. Paying money had a role only when the difference of value of goods exchanged was considerable. Money was usually not possessed by participants of exchange of goods. In addition, different kinds of money were accepted in a given country. Paying by check became generally accepted in England only in the 18th century. ${ }^{28}$

The role of work force has got great importance in the economy and for understanding legal solutions. In the often quoted work Polanyi has stressed that studies on money, work force and land cannot be limited to economics. Social relations are to be taken into consideration as well. He emphasized that regulation by the state had important role in connection with relationships concerning labour force, money and land. Self-regulation could not have decisive role. ${ }^{29}$ In general, it has also been stated that England was the only great nation to embrace free trade wholeheartedly. All other nations displayed tendencies toward free trade for some periods and only to a greater or lesser degree. Free trade was in reality but an element of a comprehensive system of economic policy. In different countries different policies can be found as a result of different social conditions. Different economic structures and conditions changed even in the same country at different times. ${ }^{30}$

Hicks has pointed out that principles of non-intervention did not cover law and state in the classical economic theory. During the 19th century more and more exceptions were admitted to the principle of non-intervention in other fields too and state intervention got importance for maintaining stability or in the interest of economic growth. ${ }^{31}$

9. As a result of the economic, social and political transformation in the 18th and 19th centuries the role of the bourgeoisie has changed and its consequences were reflected by the legal systems as well. Recognition of liberty of economic activity, abolition of privileges were examples of the changes. State activity and civil society became more and more separated. Public law concentrated on maintaining law and order, while the main field of interest of civil law was the rules of the game of the functioning of economy and society. In several European countries important political question and aim was unification of different parts of the given country, creating a unified state. Codification of civil law served the interest of the unified state, too.

\footnotetext{
${ }^{27}$ See on Hungarian development Harmathy (2019) 231-41.

${ }^{28}$ Braudel (1985) 470-75, 480-83.

${ }^{29}$ Polanyi (1946) 73-82.

${ }^{30}$ Schumpeter (1954) 397-400.

${ }^{31}$ Hicks (1959) 188-89.
} 
10. At the end of the $18^{\text {th }}$ century and beginning of the 19th century England, France and Holland were the richest countries but the Holland economy deteriorated in a short period. In England the industry developed fast, the number of population living in cities increased; there was a structural change in the pattern of economic activity, foreign trade had an important role in the development. ${ }^{32}$

In England no civil code was worked out. Law developed not in the same way as it can be observed on the European continent. Property law development was rather complicated. It was based on elements inherited from previous centuries. For an outside observer it seems that important development took place in the field of contracts. ${ }^{33}$ It is not easy, however, to understand the development of the contract law either. It seems that the development was in close connection with possibilities and forms of litigation. Legal historians consider the case of Slade v. Morley as a decisive step. It took, however, a long time until the principle of assumpsit applied in this case became generally accepted. The economic background of the acceptance of the principle was credit and payment in money. ${ }^{34}$ Later on the role of credit and of banks increased considerably. $^{35}$

An outside observer gets the impression that legal development was directed in England by practical requirements. Common law seems to be less dependent on theoretical statements than continental European laws and generalisation is less favoured than in 'civil law' countries. So it is usual to speak of the law of contracts instead of the law of contract indicating the manifold use of contract and not limiting the role of contracts to the sale of goods ${ }^{36}$ (e.g. the role of shipping, charter parties is different from that of the civil law countries). Atiyah has characterised the 18th and 19th century development saying Courts felt that they were merely working out implications of what the parties had themselves chosen to do and they were not imposing legal rules on the parties. ${ }^{37}$

11. As far as the content of the civil codes enacted in different European states is concerned the influence of liberal theories can be observed and legal rules reflecting other tendencies were enacted in separate acts of parliament. ${ }^{38}$

The French Civil Code has been characterised as conserving to some extent elements of the previous system but introducing revolutionary ideas, too. Different parts of the code reflect different ideas and the evaluation of the different parts is unequivocal. ${ }^{39}$ Family law rules were patriarchal and anti-feminist, the ownership seemed to be absolute but state regulation was important, the principle of freedom of contract prevailed but labour relations were subject to

\footnotetext{
${ }^{32}$ Cole and Deane (1966), 8-9, 44-45, 51-52.

${ }^{33}$ Sugarman and Rubin (1984) 41-43.

${ }^{34}$ Simpson (1975) 281-82, 295-99.

${ }^{35}$ Schumpeter (1949) 70-74.

${ }^{36}$ Beale, Bishop and Furmston (1995) 4-5.

${ }^{37}$ Atiyah (1971) 5 .

${ }^{38}$ Coing (1982) 7-10.

${ }^{39}$ Niort (2005) 257-89.
} 
police regulation. ${ }^{40}$ Nevertheless, principles of market economy can be found in the law of contracts. Therefore, the principle of private autonomy was supposed to prevail in the rules of the Code. Recent analysis has, however, pointed out that this interpretation of the Code was due to the theory prevailing in the second part of 19th century and was generally accepted (with limitation) in the 20th century. The analysis of the history of codification has pointed out that although liberty of contract was the basis of the rules on contracts it was limited by public order and principles of good morals. It did not mean, however, principles of individualist morals. This concept can be found in the first commentary of the code, too. ${ }^{41}$

The basis of the law of ownership was the ideology of the French revolution. The Declaration of the Rights of Man and of the Citizen of 1789 was the basis of the rules of the Civil Code (property is an inviolable and sacred right). ${ }^{42}$ Carbonnier has, however, pointed out that the main interest in regulating property concerned agricultural land. The proper protection of movables (important for industry and trade) was lacking at the time of codification. ${ }^{43}$

According to Portalis (one of the drafters of the Code) ownership was one of the basic institutions of social institutions. This special position was not an obstacle, however, to the limitation of its use by the state. The Code contained a unified regulation of ownership concerning all kinds of objects but the original conception of codification was to work out a separate code for agricultural lands (drafting a special code started already in 1801 but it stopped in 1815 without any success). ${ }^{44}$

When considering the development of the French civil law the French administrative law is to be taken into consideration as well. In 1790 courts were forbidden to proceed in cases concerning state administration (a reaction to abuse of judicial power by the king) and a separate system of adjudication evolved. At the highest level, the Conseil d'État had the task to work out drafts for legislation and to prepare decisions to be made by the first 'consul' (Napoléon) i.e. the head of state. ${ }^{45}$ A system of administrative courts was created. As a result of urbanisation, social and economic development administrative organs concluded contracts more and more often. Administrative courts got competence to decide in disputes originated from these 'administrative contracts'. Public interest was taken into consideration in cases concerning administrative contracts by the administrative courts applying principles which were different from civil law contracts. ${ }^{46}$

12. Germany was a latecomer in comparison with England and France. The unification of the German states and civil code was achieved only in late 19th century. The theory of civil law worked out during the century was the basis of the civil code. The code was the result of a precise preparatory work. It has been nevertheless severely criticised saying that it was the

\footnotetext{
${ }^{40}$ Halpérin (2001) 25-33.

${ }^{41}$ Ghestin, Loiseau and Serinet (2013) 150-52, 162-64.

${ }^{42}$ Malaurie and Aynès (2007) 108-109.

${ }^{43}$ Carbonnier (2008) 640.

${ }^{44}$ Halpérin (2001) 25, 122-23.

${ }^{45}$ Vedel and Delvolvé (1992) 103-104.

${ }^{46}$ Ghestin, Loiseau and Serinet (2013) 37-38.
} 
product of a previous period of history and could not serve as a basis for the future. ${ }^{47}$ Problems were evident from the very beginning as it was reflected by the act putting the Code into force which contained nearly 100 articles enumerating topics of special legislation. During and after World War I several Acts of Parliament were passed partly amending the Code partly as special legislation independent from the Code. ${ }^{48}$

In Germany the role of cartels got a great importance since the end of the 19th century. The tendency of centralisation and the growing role of monopolies endangered liberty of commerce. Under these conditions equal position of contracting partners was often illusory. ${ }^{49}$ As a result of the state intervention into the economy during and after the war the restrictions on state intervention were abolished, the borderlines between private and public law disappeared. ${ }^{50}$ The role of the state in the economy got more and more importance and it had serious consequences after the Nazi political takeover. The transformation of the whole legal system started.

13. Traditional central questions of the civil law were the individual person, family, property, contract, inheritance for centuries. Economic activity realised in community was usually neglected. In the 19th century, however, the role of activity pursued in (non-family) communities was increasing considerably. Technical changes, industrialisation and urbanisation changed the role and importance of units of economic activities. ${ }^{51}$ Until the 19th century usually the ruler (the state) granted the privilege to pursue some kind of economic activity on some conditions. Later on general rules specified conditions of economic activity. ${ }^{52}$ The change did not mean lessening the impact of the state but the form of the role has changed.

It was in the second part of the 19th century that the economy developed particularly fast. The greatest development of industry was realised in England, the USA and Germany. In 1870 two third of the industrial production of the world was realised in these countries. ${ }^{53}$ In France and Germany an important role was played by banks (a special category of banks: development banks evolved). State intervention was strong in countries where development of industry was late in comparison with England and USA. ${ }^{54}$ Under the new conditions new problems were to be faced such as strikes, trade unions, cartels, unfair competition, and growing importance of financial problems. The state could not be neutral particularly in presence of economic crisis situations and has found ways of intervention by means of banks even in England. ${ }^{55}$ The theory of Keynes concerning unemployment, money and the role of the state got a decisive role. ${ }^{56}$

\footnotetext{
${ }^{47}$ Wieacker (1953) 14-15.

${ }^{48}$ Mertens (2019) 4-5.

${ }^{49}$ Nörr (1994) 26.

${ }^{50}$ Stolleis (1989) 145.

${ }^{51}$ Parsons (1966) 22-26, Hoselitz (1960) 45-46, 60.

${ }^{52}$ Schmoeckel (2008) 163-64, 176-77.

${ }^{53}$ Chandler (1990) 3.

${ }^{54}$ Gerschenkron (1962) 14-15.

${ }^{55}$ Gower (1959) 156-57.

${ }^{56}$ Keynes (1936).
} 
The crisis and its consequence, the unemployment led to the increasing role of the state everywhere. The trend was accompanied with the preparation to World War II.

During World War II rationing of the different materials, labour force, food and direct state intervention prevailed in all countries. After the end of the war several years were needed for reconstruction. A wave of nationalising different parts of the economy was present in many countries changing market structure and several institutions of the civil law. A great part of the houses were destroyed, consequently living conditions were regulated by the state for many years even after the end of the war.

Changes of the role of the state, transformation of the economic and social system were reflected by the legal literature. It seems, however, that mainly some American lawyers started analysing legal institutions on basis of their social and economic background. ${ }^{57}$ Since that time a new direction of research developed in economics analysing interdependency of economic structure and legal institutions. ${ }^{58}$ In contrast to the macroeconomic approach the theory of microeconomic analysis has got influence too. ${ }^{59}$

14. After World War II important changes took place in France in political life, in the economy and in the legal field too. The Preamble of the French Constitution declared that all objects and enterprises having public service character shall be in public ownership. Closely connected with extension of public ownership state direction of market and planning was in practice. The changes continued since that time, too, to a great extent in the field of public law. ${ }^{60}$ In the field of civil law basic institutions of civil law have also been reconsidered on basis of social transformations and of changing social values. ${ }^{61}$

After World War II Germany had a special situation. The Nazi state was destroyed and for some years two German states existed. In the Federal Republic of Germany a democratic state was built with a new social and economic system. Theoretical bases of the system were to be worked out. Neither the thesis of 'point null' starting point, nor the continuity could be accepted. ${ }^{62}$ For several years theoretical discussion was going on concerning basic questions of the legal system. Among other publications a German review of legal history contained a series of important essays on fundamental questions of the new legal system. Professor Mestmäcker discussed ideas of re-establishing a civil society and its legal system of market economy and constitutional order on basis of Franz Böhm's theory. ${ }^{63}$ The discussion was continued by the public law historian Michael Stolleis on state intervention ${ }^{64}$ and several years later by the legal historian Gerhard Dilcher emphasising the importance of long-range social and economic changes in society and economy as basis of construction of the legal system (in another review of

\footnotetext{
${ }^{57}$ Commons (1924) 4-33; Horwitz (1977) 2-4.

${ }^{58}$ North (1981), North (1990), and series of articles in Journal of Institutional and Theoretical Economics.

${ }^{59}$ Posner (1973).

${ }^{60}$ On recent development Delvolvé (2017) 33-41; Blanc (2017) 76-83.

${ }^{61}$ Rochfeld (2011) formulation of the main objectives 5 .

${ }^{62}$ Stolleis (2012) 25-32.

${ }^{63}$ Mestmäcker 10 (1991) 177-92.

${ }^{64}$ Stolleis (1992) 500-507.
} 
legal history).$^{65}$ The reason of mentioning these publications is to show the broad range of problems when building a new legal system and at the same time the role of the state in a modern society and economy.

Research of legal history had other importance as well. After the national socialist period when a new legal system was created the aim was to return to the European traditions and to contribute to building a European identity in the process of integration ${ }^{66}$ In Germany research work in the field of legal history had a considerable scientific importance; on the contrary in countries belonging to the Soviet political bloc a more practical aim prevailed after the collapse of the communist bloc: returning to bases of the former system as far as it was possible.

15. As it has been indicated above the role of the state has not only changed during the last centuries but it increased considerably and the legal system as a whole has been transformed. Consequently, rules of the civil law and its role in the legal system have changed. Separate topics of the phenomenon were discussed more or less indirectly in connection with general problems of crisis situations or in the framework of reconstruction of economy and state. There are signs, however, that some general questions of the reflection by civil law and its institutions of the changing role of the state have been observed to a greater extent on international forums too not only in the legal research work of different countries. An example of the increased interest in the general topic was a comparative Franco-British dialogue in the framework of colloquia held in Oxford and Paris in 2000 and 2001. ${ }^{67}$

Another important example of the research interest of the topic of the relationship between civil law and state was the conference organised by the American Journal of Comparative Law and Rabels Zeitschrift für ausländisches und internationales Privatrecht in Hamburg in 2007. In a preparatory article for the conference Nils Jansen and Ralf Michaels have got to the conclusion that there is no 'naturally given' relation between private law and the state and modern questions of the relationship are resulting from specific historical developments. ${ }^{68}$

The discussion was going on at international level. Basedow has pointed out the importance of non-state private law rule-making in different fields mainly in international business relations. ${ }^{69}$ It has also been stated that the understanding of the connection between law and economy has an important role the background of different standpoints concerning economic theories. ${ }^{70}$ It is also to be taken into consideration that civil law covers a vast field of social relations and different parts of civil law are based on different values, social interests. ${ }^{71}$ As it can be understood from the few elements of the discussion mentioned above several starting points and several elements of the topic civil law and the role of the state should be taken into

\footnotetext{
${ }^{65}$ Dilcher (1999) 389-407.

${ }^{66}$ Jansen (2005) 204.

${ }^{67}$ Auby and Friedland (2006) 3-5.

${ }^{68}$ Jansen and Michaels (2007) 397.

${ }^{69}$ Basedow (2008) 718-21.

${ }^{70}$ Snyder (2008) 724-25.

${ }^{71}$ Dagan (2008) 810-11, 832-33.
} 
consideration. An additional element of the discussion is to be mentioned too: it is the vast field to be covered by civil law. Civil law should encompass not only economic (market) relations but many other social relations as well, such as health, education, art, media, etc.; legal doctrine should adapt to the great transformation of the twentieth century. ${ }^{72}$

Questions of civil law and state have got particular importance in countries where a system of planned economy was created in accordance with the Marxist theory. In these countries central political direction prevailed and civil law was mixed with public law elements. After the collapse of the system a new state, a new economic and legal system was to be created. ${ }^{73}$ Fundamental questions of civil law and the role of the state have theoretical and great practical importance.

\section{LITERATURE}

Atiyah, P., An Introduction to the Law of Contract (2nd ed., Clarendon 1971).

Auby, J. B. and Friedland, M., 'General Introduction' in Auby, J. B. \& Friedland, M. (eds), The Public Law/ Private Law Divide (Hart 2006) 3-5.

Basedow, J., 'The State's private law and the economy - commercial law as an amalgam of public and private law-making' (2008) 703 The American Journal of Comparative Law 704-706.

Beale, H., Bishop, W. and Furmston, M., Contract (Butterworth 1995).

Blanc, F., 'Libéralisation ou planification' (2017) 76 Revue française de droit administratif 76-83.

Block, F. and Evans, P., 'The State and the economy' in Smelser, N. J. \& Swedberg, R. (eds), The Handbook of Economic Sociology (2nd ed., Princeton University Press, Russell Sage Foundation 2005) 505-26.

Braudel, F., Anyagi kultúra, gazdaság és kapitalizmus, XV-XVIII. század (Civilisation matérielle, économie et capitalisme, XVe-XVIIIe siècle) (Gondolat 1985).

Carbonnier, J., Droit civil, Introduction (Presses Universitaires de France 1955).

Carbonnier, J., Écrits. Textes rassemblés par Raymond Verdier (Presses Universitaires de France 2008).

Carbonnier, J., Flexible Droit (10th ed., LGDJ 2014).

Chandler, A. (Jr.), Scale and Scope, The Dynamics of Industrial Capitalism (Belknap Harvard University Press 1990).

Coing, H., Europäisches Privatrecht (Beck 1989) II.

Coing, H., Handbuch der Quellen und Literatur der neueren europäischen Privatrechtsgeschichte (Beck 1982) III/1.

Cole, W. A. and Deane, P., 'The growth of national incomes' in Habakkuk, J. \& Postan, M. (eds), The Cambridge Economic History of Europe (Cambridge University Press 1966) 1-55.

Commons, J., Legal Foundations of Capitalism (Macmillan 1924).

Dagan, H., 'The limited autonomy of private law' (2008) 3 The American Journal of Comparative Law 809833.

Delvolvé, P., 'Les libertés économiques' (2017) 33 Revue française de droit administratif 33-41.

\footnotetext{
${ }^{72}$ Teubner (2008) 837-38.

${ }^{73}$ Harmathy (2019) 244-52.
} 
Dilcher, G., 'Zur Rolle der Rechtsgeschichte des 20. Jahrhunderts' (1999) 21 Zeitschrift für Neuere Rechtsgeschichte 389-407.

Gerschenkron, A., Economic Backwardness in Historical Perspective (Belknap Harvard University Press 1962).

Ghestin, J., Loiseau, G. and Serinet, Y.-M., La formation du contrat (4th ed., LGDJ 2013) I.

Gower, L., 'Legal developments, business' in Ginsberg, M. (ed), Law and Opinion in England in the 20th Century (Stevens 1959) 143-72.

Halpérin, J.-L., Histoire du droit privé français depuis 1804 (Quadrige/PUF 2001).

Harmathy, A., 'Changes in the legal system' (2019) 2 Journal of Civil Law Studies 217-52.

Heckscher, E., Mercantilism (Routledge 1994) I-II.

Hicks, J. R., Essays in World Economics (Clarendon 1959) XII.

Horn, N., 'Ein Jahrhundert Bürgerliches Gesetzbuch' (2000) 40 Neue Juristische Wochenschrift 40-42.

Horwitz, M., The Transformation of American Law (Harvard University Press 1977).

Hoselitz, B., Sociological Aspects of Economic Growth (Free Press 1960).

Jansen, N., “Tief ist der Brunnen der Vergangenheit”, Funktion, Methode und Ausgangspunkt historischer

Fragestellung in der Privatrechtsdogmatik' (2005) 27 Zeitschrift für Neuere Rechtsgeschichte 202-228.

Jansen, N. and Michaels, R., 'Private law and the State' (2007) 2 Rabels Zeitschrift für ausländisches und internationales Privatrecht 345-97.

Keynes, J. M., The General Theory of Employment, Interest and Money (Macmillan 1936).

Kodek, G., '200 Jahre Allgemeines Bürgerliches Gesetzbuch - Das ABGB im Wandel der Zeit' (2012) 3 European Review of Private Law 667-84.

Kuznets, S., The Growth of Nations (Belknap 1971).

Malaurie, P. and Aynès, L., Les biens (3rd ed., Defrénois 2007).

Mertens, B., 'Einzelgesetze statt Kodifikation im Deutschen Reich nach 1918' (2019) 41 Zeitschrift für Neuere Rechtsgeschichte 2-19.

Mestmäcker, J. E., 'Die Wiederkehr der bürgerlichen Gesellschaft und ihres Rechts' (1991) 10 Rechtshistorisches Journal 177-92.

Niort, J.-F., 'Le Code civil dans la mêlée politique et sociale' (2005) 257 Revue Trimestrielle de Droit Civil 257-89.

North, D., Institutions, Institutional Change and Economic Performance (Cambridge University Press 1990).

North, D., Structure and Change in Economic History (Norton 1981).

Nörr, K. W., Das Leiden des Privatrechts (Mohr-Siebeck 1994).

Nörr, K. W., 'Kodifikation und Wirtschaftsordnung im Deutschland des 19. Jahrhunderts: ein Fall von benign neglect?' (2001) 23 Zeitschrift für Neuere Rechtsgeschichte 51-61.

Olechowski, T., 'Das ABGB - Rechtseinheit für Zentraleuropa' (2012) 3 European Review of Private Law 685-709.

Parsons, T., Evolutionary and Comparative Perspectives (Prentice Hall 1966).

Pichler, J. W., 'Der Kampf um die Kodifikation' in Bydlinski, F., Mayer-Maly, T. \& Pichler, J. (eds), Renaissance der Idee der Kodifikation (Böhlau 1991) 10-18.

Polanyi, K., Origins of Our Times, The Great Transformation (Gullancz 1946).

Posner, R., Economic Analysis of Law (Little Brown 1973).

Robbins, L., The Theory of Economic Policy (2nd ed., Macmillan 1978).

Rochfeld, J., Les grandes notions du droit privé (PUF 2011).

Schmoeckel, M., Rechtsgeschichte der Wirtschaft (Mohr Siebeck 2008). 
Schumpeter, J. A., History of Economic Analysis (Oxford University Press 1954).

Schumpeter, J., The Theory of Economic Development (Harvard University Press 1949).

Simpson, B., A History of the Common Law of Contract (Clarendon 1975).

Smith, A., in Meek, R. L., Raphael, D. D. and Stein P. (eds), Lectures on Jurisprudence (1763) (Clarendon Press 1978).

Smith, A., The Invisible Hand (Penguin 2008).

Snyder, D. V., 'Contract regulation, with or without the State: ruminations on rules and their sources. A comment on Jürgen Basedow' (2008) 3 The American Journal of Comparative Law 723-42.

Stolleis, M., 'Auferstanden aus der Wende: Die bürgerliche Gesellschaft und ihr Recht' (1992) 11 Rechtshistorisches Journal 500-507.

Stolleis, M., 'Die Entstehung des Interventionsstaates und das öffentliche Recht' (1989) 11 Zeitschrift für Neuere Rechtsgeschichte 129-47.

Stolleis, M., Geschichte des öffentlichen Rechts in Deutschland, Vierter Band 1945-1990 (Beck 2012).

Sugarman, D. and Rubin, G. R., 'Introduction, towards a new history of law merchant and material society in England 1750-1914' in Rubin, G. R. \& Sugarman, D. (eds), Law Economy and Society 1750-1914 (Professional Boks Ltd. 1984) 41-43.

Teubner, G., 'State policies in private law? A comment on Hanoch Dagan' (2008) 3 The American Journal of Comparative Law 835-44.

Vedel, G. and Delvolvé, P., Droit administratif (12th ed., Presses Universitaires de France 1992) I.

Wieacker, F., Das Sozialmodell der klassischen Privatrechtsgesetzbücher und die Entwicklung der modernen Gesellschaft (Müller 1953).

Wieacker, F., Privatrechtsgeschichte der Neuzeit unter besonderer Berücksichtigung der deutschen Entwicklung (Vanderhoeck \& Ruprecht 1952).

Open Access. This is an open-access article distributed under the terms of the Creative Commons Attribution 4.0 International License (https://creativecommons.org/licenses/by/4.0/), which permits unrestricted use, distribution, and reproduction in any medium, provided the original author and source are credited, a link to the CC License is provided, and changes - if any - are indicated. (SID_1) 